\title{
A giant angiokeratoma of Fordyce: an uncommon cause of acute scrotum
}

\author{
Sofia Ribeiro, ${ }^{1}$ Sofia Ferreira, ${ }^{1}$ Manuel Castanheira de Oliveira ${ }^{2}$
}

${ }^{1}$ Department of Medicine, CHP, Porto, Portugal

${ }^{2}$ Department of Urology, CHP, Porto, Portugal

\section{Correspondence to}

Dr Sofia Ribeiro,

sofiaribei@gmail.com
To cite: Ribeiro $S$,

Ferreira S, de Oliveira MC. BMJ Case Rep Published

online: [please include Day

Month Year] doi:10.1136/

bcr-2013-201323

\section{DESCRIPTION}

A 34-year-old man presented to the emergency department with intense, sudden and persistent scrotal pain, worsened by the orthostatic position. He denied other accompanying symptoms such as bleeding or history of recent trauma. He referred an asymptomatic congenital angioma of the scrotum and denied any other medical history. Physical examination revealed an extensive red-to-reddish blue papules in the right hemiscrotum, with numerous dark red petechiae (figure 1). It was painful on palpation. Ultrasound revealed a general skin and subcutaneous tissue thickening with multiple dilated vessels, without testicular changes. Systemic examination was unremarkable.

Diagnosis of thrombosed angiokeratomas of the scrotum-Fordyce's angiokeratomas-was made. Since it is an acute scrotum, with uncontrolled pain due to extensive areas of thrombosis, he underwent an urgent surgery with complete excision of the angioma, without complications. Histopathological study confirmed the clinical diagnosis (figure 2). Potential precipitants such as intra-abdominal masses, urinary tract tumours, varicoceles, hernias and angiokeratoma corporis diffusum (Fabry syndrome) were excluded. After 2 years, the patient remained asymptomatic.

Angiokeratoma of the scrotum is often a benign and asymptomatic condition. ${ }^{1}$ It is a vascular dermatosis characterised by dilated vessels of the superficial dermis associated with epidermal hyperplasia. $^{2}$ The remaining skin should also be carefully examined for other lesions that may be associated with Fabry syndrome, malignant melanoma, melanocytic naevi or other pathologies. ${ }^{13}$

The curiosity of this case is the extensive lesion in a young patient, associated with an unusual

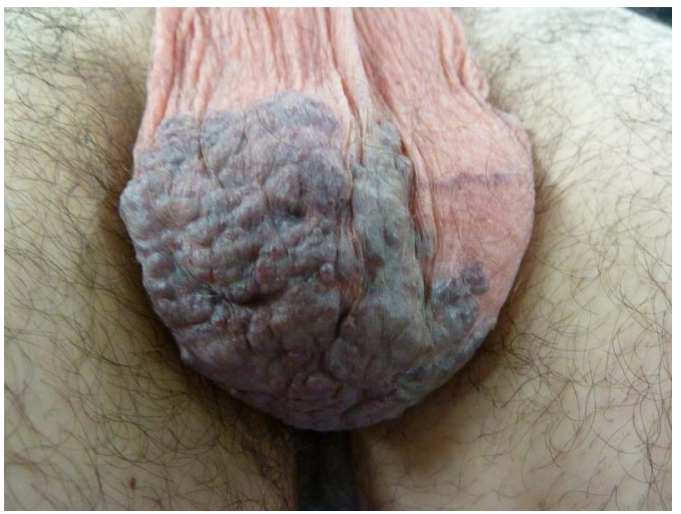

Figure 1 Multiple blue-to-red papules and numerous dark red petechiae with a scaly surface located on the right hemiscrotum.

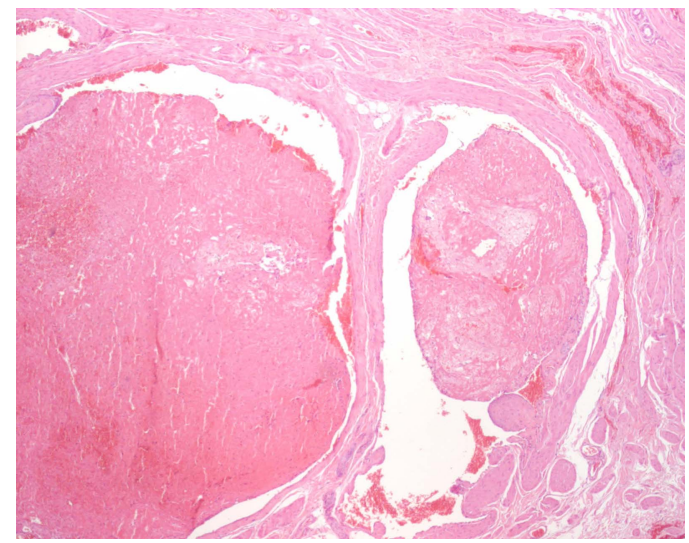

Figure 2 Haemangioma (proliferation of dilated and tortuous vessels) and it should be noted the presence of fibrin thrombi in the lumen of some blood vessels.

symptomatic presentation of intense pain due to vascular thrombosis, without haemorragy, requiring an urgent surgical intervention.

\section{Learning points}

Scrotal angiokeratoma of Fordyce often arise in the second or third decade but are most commonly diagnosed in elderly men and is frequently asymptomatic benign lesion.

- Although the most frequently described first presentation is bleeding, there are a few cases presenting extensive thrombosis with an uncontrolled pain, making it difficult to diagnosis.

- Should be excluded other possible associated diseases such as angiokeratoma corporis diffusum (Fabry syndrome), intra-abdominal masses, urinary tract tumours, varicoceles, hernias, malignant melanoma and melanocytic naevi.

Contributors The conception of the article and literature revision were made by SR and MCDO. Final revision was conducted by SF.

Competing interests None.

Patient consent Obtained.

Provenance and peer review Not commissioned; externally peer reviewed.

\section{REFERENCES}

1 Trickett R, Dowd H. Angiokeratoma of the scrotum: a case of scrotal bleeding. Emerg Med J 2006;23:5-7. 
2 Gioglio L, Porta C, Moroni M, et al. Scrotal angiokeratoma (Fordyce): histopathological and ultrastructural findings. Histol Histopathol 1992;7:47-55.
3 Hogarth $\mathrm{V}$, Dhoat $\mathrm{S}$, Mehta $\mathrm{AB}$, et al. Late-onset Fabry disease associated with angiokeratoma of Fordyce and multiple cherry angiomas. Clin Exp Dermatol 2011;36:506-8.

Copyright 2013 BMJ Publishing Group. All rights reserved. For permission to reuse any of this content visit http://group.bmj.com/group/rights-licensing/permissions.

BMJ Case Report Fellows may re-use this article for personal use and teaching without any further permission.

Become a Fellow of BMJ Case Reports today and you can:

- Submit as many cases as you like

- Enjoy fast sympathetic peer review and rapid publication of accepted articles

- Access all the published articles

- Re-use any of the published material for personal use and teaching without further permission

For information on Institutional Fellowships contact consortiasales@bmjgroup.com

Visit casereports.bmj.com for more articles like this and to become a Fellow 